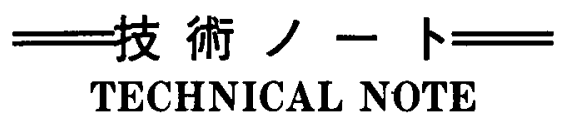

\title{
衛星球形タンク内液体の功的挙功解明のための二つの試験*1 \\ Experimental Investigation on the Dynamic Behavior of the Liquid in Spherical Tanks of a Spinning Satellite
}

\author{
小松 敬 治*2 - 小 野 修 壽*3 \\ Keiji Komatsu, Syuji ONo \\ 清 水順一 郎*3 ・長 島 隆一*3 \\ Junichiro SHIMIZU, Ryuichi NAGASHIMA \\ 安澤 真 一*4 \\ and Shinichi ANZAWA
}

Key Words : Artificial Satellites, Oscillation, Sloshing, Spherical Tank, Spin

\begin{abstract}
Two experiments are carried out to investigate the dynamic behavior of the liquid partially filled in spherical tanks of a spinning satellite. One is the simulation test at the spin up phase of the rocket. The other is the sloshing test to analyze the propellant sloshing effects on the satellite attitude control. These experiments are specially set for the Engineering Test Satellite $\mathrm{V}$ which has two spherical tanks $37 \%$ filled with hydrazine, but the results obtained can be applicable to the other problems of the liquid dynamics in spherical tanks.
\end{abstract}

\section{1. 序論}

昭和 62 年に H-I ロケットで打ち上げ予定の ETS$\mathrm{V}$ (技術試験衛星 V 型) は姿勢制御用に二つの液体推 薬（ヒドラジン）タンクを備えているが，ミッション 遂行上, 内部夜体の動的挙動に関して問題点が指摘さ れた.タンクは 5 年分の推薬が入る設計であるが、 ETS-Vのミッション期間は 1 年半てあるため, タン ク充填率が 37\%であることが原因となっている。一 つはロケット姿勢制御フェースでのスピンアップ時の 衛星内液体の大変形に関するもの，もう一つはアポシ モーター燃焼フェースでの液体のスロッシングが衛星 の軌道投入誤差へ及住す影慗に関するものである.

\footnotetext{
*)昭和 61 年 7 月 17 日，第 28 回権造強度に関する講演会に て発表. 昭和 61 年 8 月 12 日原稿受理

*2 航空宇宙技術研究所

*3 宇宙開発事業団

*4 石川島播磨重工業(株)
}

このニつの問題についてスピンアップ試験とスロッ シング試験とを行ったが，得られた結果は液体の動的 挙動問題について一般性を持ち，しかも，この種の報 告は従前なされていないので、ここに報告する次第て ある。

\section{2. スピンアップ試験}

ETS-V (第 1 図)をぺイロードとする H-I ロケット は，固体 3 段モーター燃焼開始前に 3.5 秒間て 90 rpmにスピンアップするが，スピンアップ完了後， 3 段モータ点火までのロケット姿勢制御フェースに対 する影瞥として，衛星内の夜体の振動があるのかない のか、また，あるとすればどの程度の振幅が残るのか が問題となった．スピンアップ前にはほとんど無重力 状態にあると予测されるが、制御による残留加速度が かかっている可能性もあり，最悪の状態として第 1 図

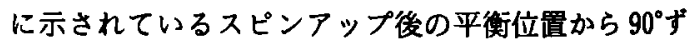
れた位置に一塊として存在していた場合を採用した。 この位置からの移動が有害な横スロッシングを最も大 きく誘起する，このような問題についての試験例は報 告されておらず，また，信頼のおける解析法もみあた らなかったので、以下のように $1 g$ の重力下でシミュ レーション試験を行うこととした．供試体は実機相当 の内径 $53 \mathrm{~cm}$ の球形アクリルタンクを用いて行っ た。

第 2 図に試験装置の概要を示す. 推薬のヒドラジン の物性は水に近いのて，内部夜体は水で代用した．内 部液体の運劰は 4 チャンネル（ch）の波高計の出力を 


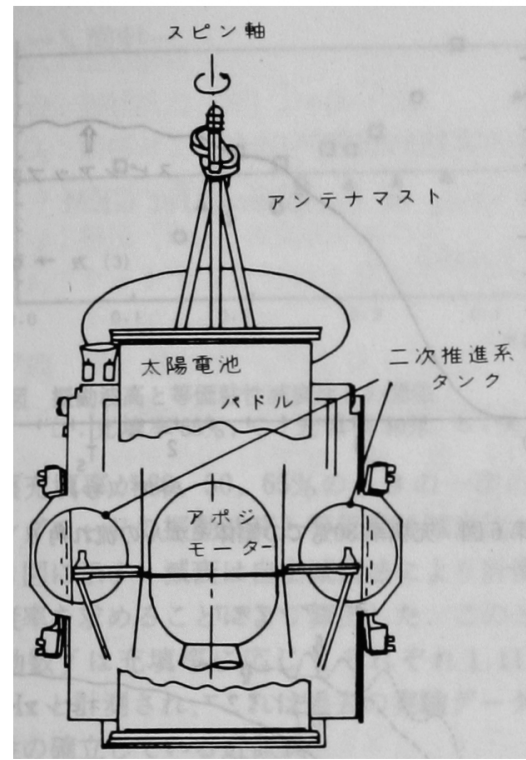

第 1 図 ETS-V

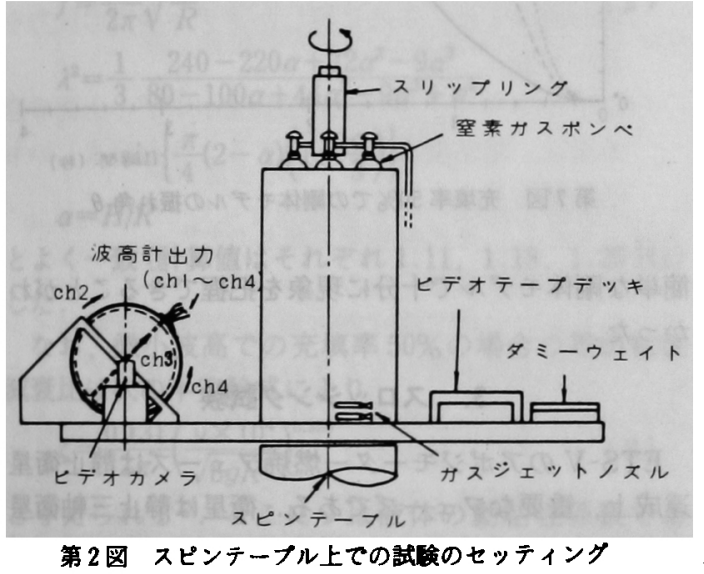

記録するとともに，ビデオカメラでモターしたま た，スピンは窒素ガスのジェットにより与えた．充填 率か3 $30 \%$ と 50\%の波高計の結果を第 3 図と第 4 図と に示す.図にお゙いて, ch.1 と ch.3 とが回転方向に直角 に貼ってある波高計の出力て，初期の振動は静止状態 からの急な回転加速により，液体が回転逆方向に移動 したために生じたことがビデオ画像で確認された.ch. 2 と ch.4 とが遠心力方向の波高計出力であり，スピ ンアップ完了後, たかたか $1 \sim 2 \mathrm{~cm}$ 程度の振幅のス ロッシングしか生じていない，この試験は $1 g$ 下で行 ったが，90 rpm は $8 g$ 程度の加速度に相当するのて， 無重力状態てもスピンアップ後の釣合い位置が異なる 程度で，定性的には $1 \mathrm{~g}$ の影赠は無視しうる。この試 検の結果, ETS-Vについてはスピンアップ完了後。 3段モーター点火まてのロケット姿然制御フェースに

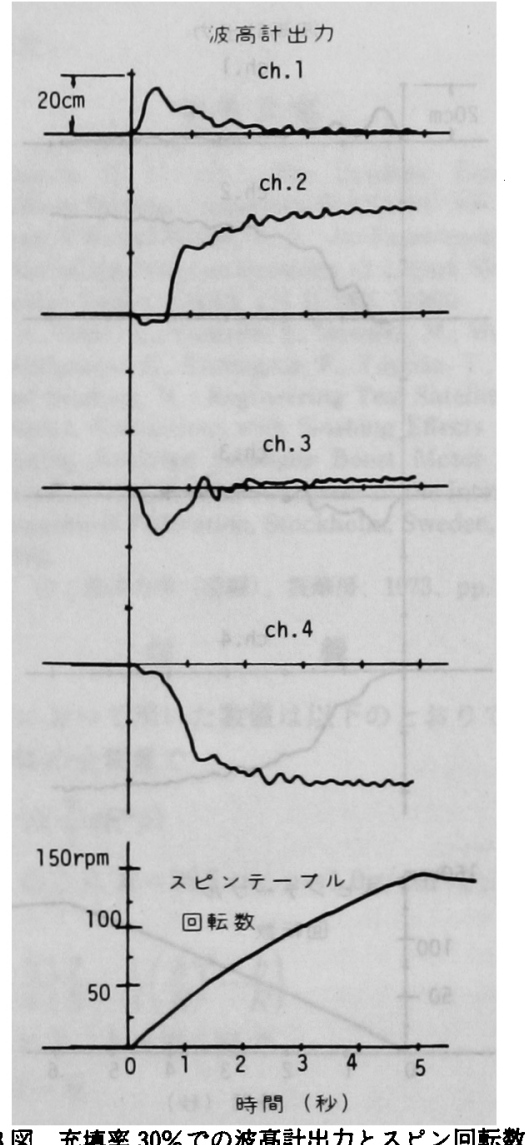

第 3 図 充填率 30\%で波高計出カとスピン回転数

対しては，液体の振動は問題としなくてよいことがわ かった。一方，液体を第 5 図に示すような䣓体振り子 とみなして振れ角 $\theta$ についてたてた運動方程式

$$
\begin{aligned}
& m l \frac{d^{2} \theta}{d t^{2}}+c l \frac{d \theta}{d t}-m \Omega^{2}(t)(L+l \sin \theta) \cos \theta \\
& \quad+m g \sin \theta=0
\end{aligned}
$$

をルンゲークッターギル法により数値櫴分した結果を第 6 図と第 7 図とに示す：この結果は第 3 図と第 4 図の ch.2 に対応する．計算に用いたパラメータの值につ いては付録に示す．図の実線は振り子の振れ角 $\theta$ の 動きを表しており，スピンアップ完了後にはそれそれれ 振り子としての自由減衰をすることになる.実際に は、スピンアップ完了後の運動はスロッシングとな り，スロッシングの固有振動数と振り子のそれとは異 なるので，この計算で意味があるのはスピンアップ完 了まで経過と初期振幅である，計算ての初期片振幅 は波高計での出力に換算して，充填率 $30 \%$ のを $R \theta$ $=0.7 \mathrm{~cm}$ ，充填率 $50 \%$ のとき $R \theta=0.5 \mathrm{~cm}$ となり. 計 算結果と試験結果とは定性的によく一致していると考 えられる、スピンアップに要する時間を変えて計算し 


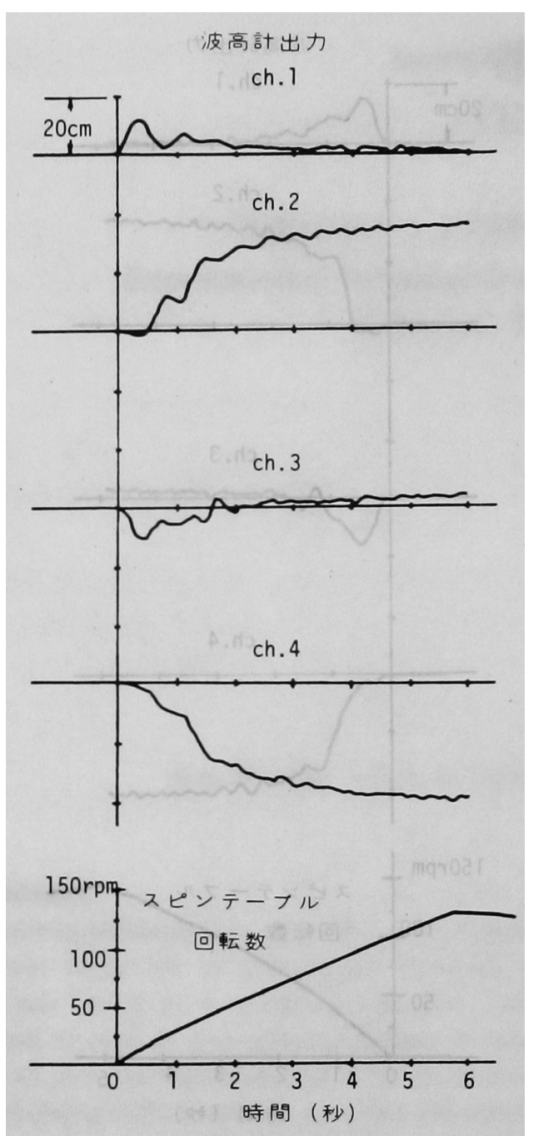

第 4 図 充填率 $50 \%$ での波高計出力とスピン回転数

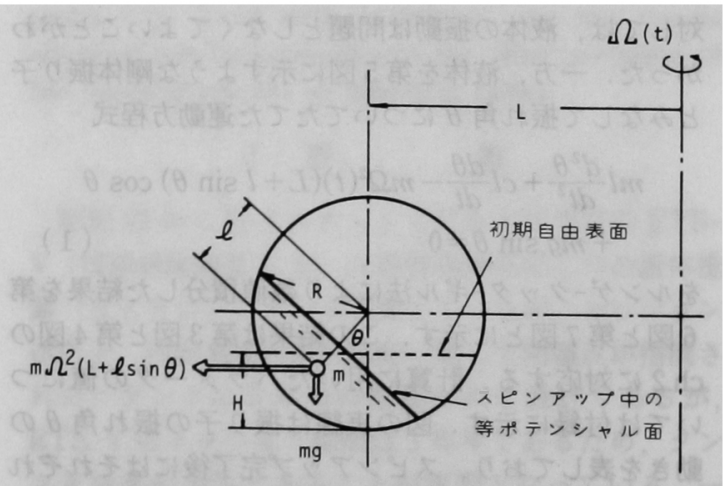

第 5 図液体の用体振り子モデル

たものを第 7 図に重梧きして示すが．時間が短けれ ば大きな振動が生ずる可能性があることも明らかとな った，また，隇衰には等価粘性隇衰比として $0.3 \%$ を いれて計算したが，無減衰として計算しても結果は図 にプロットすればほとんど重なり，減衰は二次的効果 しかないこともわかった.よって，このような場合に はナビエーストークス方程式をもちだすまでもなく，

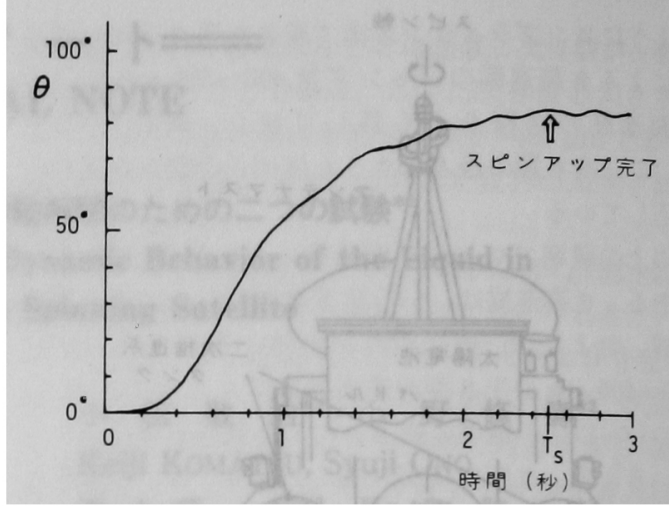

第6図 充填率 $30 \%$ で刚体モデルの流れ角 $\theta$

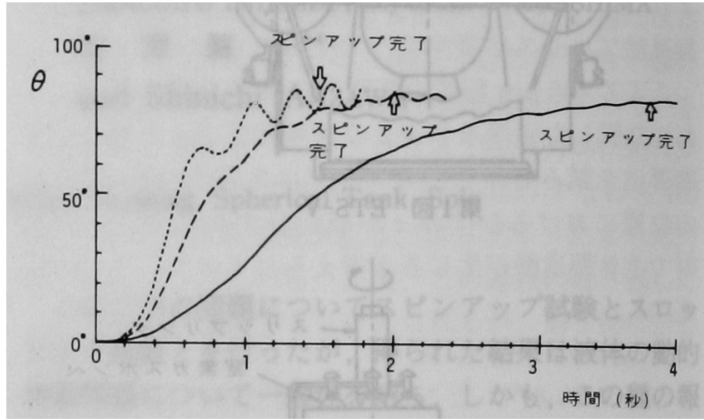

第 7 図 充填率 $50 \%$ での琂体モデルの振れ角 $\theta$

簡単な剛体モデルで十分に現象を把挃できることがわ かった.

\section{3. スロッシング試験}

ETS-Vのアポジモーター燃焼フェースは静止衛星 達成上，重要なフェースである。衛星は静止三軸衛星 であるが、アポジモーター燃焼フェーズではまだスピ ンをしている。この過程でスロッシングは、アポジモ ーターの推カミスアライメント, 衛星の重心オフセッ ト，衛星のスピン軸と機械軸とのずれなどとともに， 軌道投入椌差の一因となりうる.スロッシングの軌道 投入誤差への影響を解析するのに必要な基礎データを 取得するため，スロッシングに関する試験を行った.

スロッシングについては，すでに多くの研究がなさ れてきているが立，そのほとんどが， 円筒タンクに関 するものて，球形タンクについての数は少ない．線形 の筑囲てはあらためて試験をする必要はないが, 大変 形時での減衰特性を求めることを主目的として試験を 行った．大変形時の隇衰については文献"2があるが，

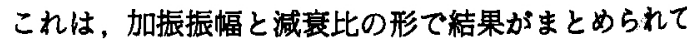
いる．制御では波高振幅と減衰比との関係が必要であ り．しかも非線形領减では寸法効果があるので，実機 相当のタンクでのデータが必要であった. 


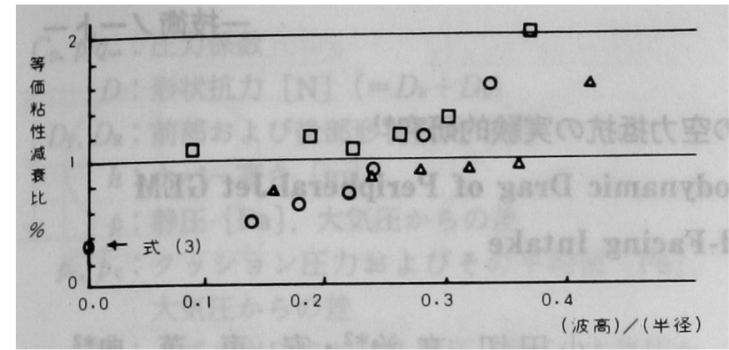

第 8 図 振㢦波高と等価粘性減衰比との閶係

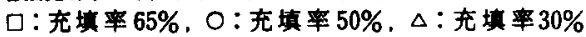

推薬充填率が $30,50,65 \%$ のときの一次の横スロ ッシングモードの振動波高と等価粘性隇衰比との関係 を第8図に示す．隇衰は自由減衰法により計測し，対 数滅衰率を求めることにより算出した，このときの固 有振動数 $f$ は充填率に応じてそれぞれ 1.11，1.21， $1.30 \mathrm{~Hz}$ と計測され，これは過去の実験データにより 信頼性の確立している近似式”

$$
\begin{aligned}
f= & \frac{\lambda}{2 \pi} \sqrt{\frac{g}{R}} \\
\lambda^{2}= & \frac{1}{3} \frac{240-220 \alpha+72 \alpha^{2}-9 \alpha^{3}}{80-100 \alpha+44 \alpha^{2}-9 \alpha^{3}+\alpha^{4}} \\
& \cdot \sin \left\{\frac{\pi}{4}(2-\alpha)\left(1+\frac{\alpha}{3}\right)\right\} \\
\alpha= & H / R
\end{aligned}
$$

した.

なお，微小波高ての充填率 $50 \%$ の場合の等価粘性 減衰比は次の半実験式により

$$
\zeta=\frac{0.131}{2 \pi}\left(\frac{\nu \times 10^{4}}{\sqrt{8 g R^{3}}}\right)^{0.359}
$$

と与えられる゙2.ここにレは液体の動粘性係数であ る.この式による值も第 8 図に付記する.第 8 図の関 保をもとにスロッシングのメカニカルモデルの減衰部 を作ることにより，より実体に近いシミュレーション 解析"が可能となった。

\section{4. 結}

\section{商}

ETS-Vで指摘された液体の動的挙娌問題解決のた めに試駼を行って，当初の目的を達成し，さらに，次 のような一般性のある結果を得た。

1) 球形タンク内の液体のスロッシングの等価粘 性減衰比は波高が大きくなると增大するが，これを， 液面波高と等価粘性減衰比の形でとめた。

2）球形タンク内液体のスピンアップ時の過渡応 答解析には第一近似として网体モデルを用いればよい ことが武硂により確認された。

3) 球形タンク内液体のスピンアップ時には，減 衰は二次的奻果しかないことが計算と試酫により明ら
かとなった

\section{容考文献}

1) Abramson, H. N. (ed.): The Dynamic Behavior of Liquids in Moving Containers, NASA SP-106 (1966).

2) Sumner, I. E. and Stofan, A. J. : An Experimental Inves. tigation of the Viscous Damping of Liquid Sloshing in Spherical Tanks, NASA TN D-1991 (1963).

3) Ono, S., Ueno, K., Yamada, S., Miwada, M., Murayama, H., Nakamaru, K., Yamagata, F., Toyoda, T., Hiwada, T. and Inomata, H. : Engineering Test Satellite V Spin Dynamics, Simulations with Sloshing Effects and Geostationing Analyses (Apogee Boost Motor Burning, Precession, Despin), 36 th Congress of the International Astronautical Federation, Stockholm, Sweden, IAF-8576, 1985.

4) 今井 功：流体力学 (前編)，㫫華房，1973，pp. 291-300.

付

\section{録}

式(1)において用いた数值は以下のとおりである. $m:$ 液体の全質量て

$$
m=V_{1}\left(\frac{4}{3} \pi R^{3} \rho\right)
$$

となる.ここに $R=26.5 \mathrm{~cm}, \rho=1.0 \mathrm{~g} / \mathrm{cm}^{3} て$ ，充填率 V、は

$$
V_{1}=\frac{3}{4}\left\{\frac{2}{3}+\frac{1}{3}\left(\frac{b}{R}\right)^{3}-\frac{b}{R}\right\}
$$

と与えられる。 $b$ は第 5 図て

$$
b=R-H
$$

と定義される.

$l:$ 液体の重心と球形タンクの中心との距離て

$$
l=\frac{3}{8} R \frac{1-2\left(\frac{b}{R}\right)^{2}+\left(\frac{b}{R}\right)^{4}}{1+\frac{1}{2}\left(\frac{b}{R}\right)^{3}-\frac{3}{2}\left(\frac{b}{R}\right)}
$$

となる。

$c$ ：隇衰係数で，等価粘性隇衰比 $\zeta$ と固有振動数 $f$ により

$$
c=4 \pi \zeta \mathrm{fm}
$$

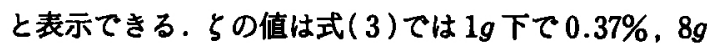
下で $0.26 \%$ となるが，この值は微小変形のスロッシ ングの隇衰比であるので，もう一つの評価として液体 と接する振動平板の理論(低速すべり運動を仮定)" を 用い，球形タンクの濡れ部分を同じ面樌の平板として 求めると $0.35 \%$ となる。よって，計算には $0.3 \%$ を採 用した．なお，水の動粘性係数は $\nu=0.01 \mathrm{~cm}^{2} / \mathrm{s}$ とした.

$L: 75 \mathrm{~cm}$

$\Omega(t)$ : スピン回転数. スピンアップ完了時間を $T$ として

$$
\begin{array}{ll}
0 \leqq t<T \tau & \Omega(t)=9.425 t / T \\
T \leqq t て ゙ & \Omega(t)=9.425 \text { (90 rpm に相当) }
\end{array}
$$

